\title{
Sukupolven käsite ja sateenkaarevan nuoruuden muistaminen
}

\author{
Riikka Taavetti
}

S ukupolven käsite on keskeinen niin nuoruuden tutkimukselle, nuoruuden historian tutkimukselle kuin nuoruuden muistamisen tutkimukselle. ${ }^{1}$ Nuoruus ehkä selvemmin kuin mikään muu ikä määrittyy suhteessa sukupolviin ja niitä jakaviin tai yhdistäviin kokemuksiin. Tutkimuksessa toisinaan sukupolven käsitettä rakennetaan suhteessa suuriin yhteiskunnallisiin murroksiin, mutta toisinaan sukupolvea määrittäviksi kokemuksiksi riittävät yhteiset nuoruuden muistot populaarikulttuurin ilmiöistä. Sukupolvi on nuoruuden muistelussa keskeinen käsite niin tutkijan työkaluna kuin myös muistelijoiden itse nimettynä "retorisena välineenä" (Vehkalahti ja Suurpää 2014, 14), tapana liittyä muistelussa ikäisiinsä tai tehdä eroa toisiin.

Pohdin tässä katsauksessa, miten sukupolven käsite taipuu, kun sitä tarkastellaan sateenkaarinuoruuden muistamisen näkökulmasta. Jatkan osaltani nuoruuden muistamisen, muistelun ja kerronnan näkökulmasta sukupolven käsitettä koskevaa pohdintaa, jonka aloitimme Jukka Lehtosen kanssa artikkelissamme sateenkaarinuorten tutkimuksen metodologisista ja eettisistä kysymyksistä (Lehtonen ja Taavetti 2018). Keskustelen nuorisotutkimuksellisen kirjallisuuden sukupolvinäkemysten, queer-teoreettisten näkökulmien sekä oman Hyvinvoiva sateenkaarinuori -tutkimushankkeessa tekemäni tutkimuksen (Taavetti 2015a) ja erityisesti siihen kuuluvan Sateenkaarinuorena nyt ja ennen -kirjoituskokoelman (ks. myös Taavetti 2016) kanssa.

Sukupolven ohella katsaukseni keskeisiä käsitteitä ovat sateenkaarevuus ja sateenkaarinuoruus. Tarkoitan sateenkaarevuudella seksuaalisuutta ja sukupuolta rajaavien normien ulkopuolelle asettumista tai elämää, joka näyttäytyy ainakin ympäristön näkökulmasta näiden normien haastamisena. Pohdin, miten sateenkaarevuus sekä mahdollinen sateenkaarinuoruuden eriaikaisuus vaikuttavat sukupolven käsitteen käyttöön ja kysyn, mitä uutta nuoruudenkokemusten moninaisuuden huomioiminen voisi tuottaa sukupolvea koskeviin käsityksiin. Kirjoitukseni viimeisessä osassa hahmottelen, millaisia voivat olla sateenkaarinuoruuden sukupolvikokemukset. Aloitan kuitenkin pohtimalla niin sukupolven kuin

Tämän kirjoituksen ensimmäinen luonnos syntyi Nuorisotutkimuspäivillä 2017 kokoontuneen työryhmän "Lapsuuden ja nuoruuden kertominen muistitiedossa" esitelmäksi. Haluan kiittää työryhmän keskusteluihin osallistuneita kommenteista ja kysymyksistä. Lisäksi haluan kiittää dosentti Jukka Lehtosta sekä tutkijatohtori Ulla Savolaista käsikirjoitustani koskeneista arvokkaista huomioista. 
sateenkaarevuudenkin merkityksiä suomalaisessa nuorisotutkimuksessa erityisesti näkökulmista, joita pidän muistelun tutkimisen kannalta keskeisinä.

\section{Sukupolvi ja sateenkaarevuus}

Mikko Piispa kuvaa 1980-luvulla syntyneiden Y-sukupolvea koskevassa kirjassaan osuvasti, miten sukupolvi on käsitteenä "hankala ja liukas, eikä siihen saa otetta vain yhdestä kulmasta" (Piispa 2018, 11). Sukupolvea käytetään tutkimuksessa toisinaan kuvaamaan arkista ymmärrystä siitä, miten eri ikäiset eroavat toisistaan. Lisäksi sukupolven käsite voi tutkimuksessa olla yhtäältä oman nuoruutensa muistelijoiden työkalu ja toisaalta tutkijoiden väline. Sukupolven käsite jakautuu analyyttisessä mielessä perhesukupolviin ja yhteiskunnallisiin sukupolviin, samanikäisten muodostamiin "yhteiskunnallisiin aaltoihin" (Häkkinen 2013, 23). Näitä yhteiskunnallisia sukupolvia on toisaalta analysoitu suhteessa äkkinäisiin, koko yhteiskuntaa muokanneisiin muutoksiin kuten sotiin ja kriiseihin sekä toisaalta suhteessa ihmisten elinolojen muutoksiin, jotka ovat ehkä olleet hitaampia, mutta joiden vaikutus on ollut yhtä perustava (jälkimmäisestä näkökulmasta esim. Häkkinen 2013; Roos 1987; Hoikkala ja Paju 2008).

Yhteiskunnallinen sukupolvi nuoruuden tutkijoiden käsitteenä on usein inspiroitunut Karl Mannheimin ajattelusta. Mannheimin artikkelissaan "Das Problem der Generationer" (englanninnos Mannheim 1952) jo vuonna 1928 esittämän mallin mukaan yhteiset kokemukset nuoruudessa, noin 17 vuoden iässä, saattavat muodostaa samanikäisistä kokemuksellisen sukupolven. Mikäli jokin yhteiskunnallinen muutos ohjaa kokemuksellisen sukupolven jäsenet osallistumaan oman aikansa keskeisiin liikkeisiin, syntyy mobilisoitunut sukupolvi (Mannheimin sukupolvikäsitteistön suomennoksista ks. Virtanen 2001, 30-33). Suomen historian sukupolvia koskevissa tutkimuksissaan Matti Virtanen $(2001 ; 2003)$ on kehittänyt oman versionsa Mannheimin mallista. Virtanen korostaa poliittisten traditioiden merkitystä ja sitä, millaisiin asemiin eri sukupolviin kuuluvat asettuvat poliittisissa traditioissaan. Tällöin yhteiset kokemukset rakentavat sukupolvia, mutta poliittiset traditiot erottavat samaan sukupolveen kuuluvia toisistaan ja yhdistävät heitä omat traditionsa aiempiin polviin.

Myös Aino Tormulainen (2018) hyödyntää tuoreessa väitöskirjassaan Mannheimin sukupolvianalyysia, vaikka Tormulaisen käsittelyssä sukupolvikokemus rakentuu populaarikulttuurin, ei niinkään merkittävien ja koko yhteiskuntaa ravistelleiden muutosten, kautta. Tormulainen $(2018,38)$ määrittelee, että nykyinen globaali populaarikulttuuri tuottaa "kevyempiä" avainkokemuksia kuin Mannheimin alun perin analysoimat yhteiskunnan suuret murrokset ja huomauttaa, että populaarikulttuurin kiivastahtisuus saattaa estää varsinaisten yhteistä identiteettiä tuottavien kokemusten syntymisen. Nuoruuden muistamisen näkökulmasta populaarikulttuurin sukupolvea muovaava merkitys on mielenkiintoinen sikäli, että esimerkiksi nuoruuden musiikkimuistoja voidaan käyttää palauttamaan mieleen nuoruudenaikaisia tunnelmia (esim. Salasuo 2014; Jokinen 2003) ja sukupolvia voidaan tuottaa jälkikäteisesti pohtimalla yhteisessä muistelutyössä, millaisia merkityksiä nuoruuden vaikutteilla on ollut (esim. Tormulainen 2018).

Erilaiset sateenkaari-alkuiset termit ovat viime vuosina yleistyneet seksuaali- ja sukupuolivähemmistöjä koskevassa keskustelussa, kun puhutaan esimerkiksi sateenkaarinuorista tai sateenkaariperheistä. Niiden hyöty on kielellisesti kömpelöiden termilitanioiden ja lyhenteiden (kuten LHBTIQ) välttäminen, sekä sateenkaareva-termin käyttäminen 
adjektiivinomaisesti ja joustavasti ilman kytköstä tiettyihin nimettyihin identiteetteihin. Sateenkaari-alkuisten termien käyttöön liittyy kuitenkin myös ongelmia: ne saattavat korostaa sateenkaarevien kokemusten erilaisuutta verrattuna esimerkiksi muihin nuoruuden kokemuksiin tarpeettoman paljon. Lisäksi sateenkaari-alku johdattaa ajattelemaan positiivisia ja valoisia puolia: tyypillisesti puhutaan esimerkiksi kyllä sateenkaariperheistä, muttei sateenkaariväkivallasta (ks. tarkemmin Taavetti 2018, 57-58). Tässä katsauksessani sateenkaareva nuoruus kattaa seksuaali- ja sukupuolivähemmistöihin kuuluvien ihmisten nuoruuden, mutta myös sellaiset nuoruuden kokemukset, jotka eivät osu nimettyihin vähemmistöidentiteetteihin. Erityisesti nuoruudessa monet eivät halua nimetä omaa seksuaalisuuden tai sukupuolen kokemustaan, minkä vuoksi liikkuvuuden salliva ja nimettyihin identiteetteihin sitoutumaton sateenkaarevuuden käsite on perusteltu (Taavetti 2015b; Taavetti 2015a; Lehtonen 2014; nuorten identiteettimäärittelyistä ks. myös Lehtonen 1998).

Sateenkaarikäsitteiden sekä hyöty että haitta voi olla se, miten ne yhdistävät yhden nimikkeen alle esimerkiksi eri sukupuolia olevien, eri tavoin identifioituvien ja hyvin eri tavoin seksuaalisuuden ja sukupuolen normeja haastavien ihmisten kokemuksia. Näistä kaikista syistä sateenkaariterminologian suhteen on syytä noudattaa tarkkuutta ja pohtia, miksi ja miten termejä kulloinkin käytetään. Erityisesti menneisyyden ja muistelun tutkimuksen näkökulmasta on keskeistä myös, että sateenkaari-alkuiset termit ovat hyvin uusia. Muistelua tutkittaessa tuleekin huomioida, miten erilaiset menneisyyden ilmiöt saattavat yhdistyä nykyisten käsitteiden avulla toisiinsa tavalla, joka ei olisi ollut aikaisemmin mahdollista. Esimerkiksi transmiehen tai aseksuaalin naisen nuoruusmuistot, joista molemmista Sateenkaarinuorena nyt ja ennen -keruun vastauksissa kerrottiin, eivät olisi välttämättä yhdistettävissä yhteisen nimittäjän alle ilman sateenkaarinuoruuden käsitettä.

Joustavuudessaan ja pysyviksi oletetuista identiteeteistä irtautumisessaan sateenkaarikäsitteet muistuttavat queer-käsitettä. Queer, jolle ei ole vakiintunutta suomennosta, viittaa 1990-luvulta alkaen kehitettyihin identiteettikriittisiin teoretisointeihin sukupuolesta ja seksuaalisuudesta. Queer pakenee tarkkoja määritelmiä ja sen määrittelemättömyyttä voidaan pitää jopa koko teorian käyttökelpoisuuden yhtenä perusteena. Jos sukupuolta ja seksuaalisuutta halutaan tarkastella liikkuvina ja joustavina, ei niiden tarkasteluun tarvittava teoriakaan voi olla lukkiutunut tarkkoihin määritelmiin. (Queer-teoriasta esim. Hekanaho 2010; teorian varhaisena yleisesittelynä ks. Jagose 1996.) Tässä katsauksessa käytän sateenkaari-käsitettä, koska se suomenkielisyytensä vuoksi taipuu paremmin adjektiivinomaiseen käyttöön. Lisäksi sateenkaarevuus on nähdäkseni suomenkielisessä keskustelussa queeria enemmän yleisen kattokäsitteen asemassa, ja siksi se on helpompaa irrottaa yksittäisten ihmisten omista itsemäärittelyistä (tai niiden puuttumisesta). Käytän queer-käsitettä kuitenkin viitatessani sellaisten tutkijoiden teksteihin, jotka itse käyttävät sitä. ${ }^{2}$

\section{Nuoruus ja sukupolvet sateenkaarevassa ajassa}

Mannheimin sukupolvimallia ja Virtasen kehittelemää sovellusta on kritisoitu siitä, että ne painottavat julkisia poliittisia kokemuksia sukupolvea muokkaavina tapahtumina ja näin tuottavat sukupolvista helposti hyvin miehisesti painottuneen mallin. ${ }^{3}$ Sateenkaarevien

\footnotetext{
2 Tarkoitukseni ei ole tarjota sateenkaarevuutta queer-käsitteen suomenkieliseksi käännökseksi, sillä se ei mielestäni vastaa sitä teoreettista asemaa, joka queerilla on.

3 Mannheimin sukupolvimallin miehisyyden kritiikistä yleisesti ks. esim. Jõesalu 2016, 559; Virtasen sukupolvimallin kritiikistä ks. Vuori ja Ronkainen 2002.
} 
nuoruudenkokemusten analysointi tarjoaa lisää mahdollisuuksia katsoa sukupolvia toisin ja joskus jopa kyseenalaistaa sukupolvittumista kokonaan. Samalla se kannustaa analysoimaan tarkemmin, keiden muistoja sukupolvikokemukset oikeastaan kattavat ja ketkä jäävät mahdollisesti niiden ulkopuolelle.

Sateenkaarinuoruuden ja sukupolven käsitteen välisen suhteen kannalta queer-teoreettinen keskustelu ajasta tarjoaa hedelmällisiä teoreettisia näkökulmia. Queerista ja ajasta 2000- ja 2010-luvuilla käydyissä keskusteluissa on kritisoitu ajatusta ajan lineaarisesta etenemisestä ja edistyksestä sekä analysoitu niitä normatiivisuuksia, jotka syntyvät yhteiskunnan suuntautumisesta kohti parempaa tulevaisuutta (ks. esim. Edelman 2004; Ferguson et al. 2007; Freeman 2007). Lisäksi queer näkökulmana nuoruuteen ja elämänkulkuun saattaa auttaa kyseenalaistamaan nuoruuden ja aikuistumisen määrittelytapojen normatiivisuuksia ja kysymään, miten nuoruutta voi sekä elää että muistaa toisin.

Eräänä nuoruuden ikäkauden tunnuspiirteenä pidetään usein heräävää seksuaalisuutta ja oman sukupuoli-identiteetin vahvistumista aikuisen miehen tai naisen identiteetiksi. Esimerkiksi Virtanen $(2003,39)$ määrittelee nuoruuden yhdeksi etapiksi itsen ulkopuolisen katseen omaksumisen: "miltä minä (varsinkin vastakkaisen sukupuolen silmissä) näytän". Samoin Tormulainen $(2018,192-197)$ käsittelee erityisesti heteroseksuaalisuuden merkitystä tyttöenergiailmiön kokemisessa. Hän arvioi, etteivät esimerkiksi seksuaali- tai sukupuolivähemmistöihin kuuluvat tytöt välttämättä samastuneet tähän sukupolvikokemukseen, mutta toisaalta hän kuitenkin korostaa, että muistelijoidenkin itseymmärrykset saattoivat olla moninaisia ja että tyttöenergia saattoi tarjota myös vaihtoehtoisia samastumisen mahdollisuuksia (Tormulainen 2018, 61). Vaikka Tormulainenkin (2018, 37-38) määrittelee sukupolven samanikäisten yhteisten kokemusten muovaamaksi, huomion kiinnittäminen näiden kokemusten heteroseksuaalisuuteen osoittaa, että kokemukset eivät ole kaikille samanikäisille välttämättä samanlaisia ja yhtäläisesti sukupolvikokemusta muovaavia.

Mikäli esimerkiksi nuoren syntymässä määritetty sukupuoli ei ole oikea tai hän ei ole kiinnostunut "vastakkaisen sukupuolen" edustajista, hän ei välttämättä koe ainakaan muiden kanssa samanaikaisesti niitä nuoruudelle ominaisia kokemuksia, joihin monet sukupolvien määrittelyt perustuvat. Tätä eriaikaisuutta on joskus käsitteellistetty "myöhästyneenä murrosikänä" (Lehtonen 2006, 58), jota voidaan elää vasta, kun oma suhde seksuaalisuuteen ja sukupuoleen on vähemmän jännitteinen ja on mahdollista elää hyväksyvissä yhteisöissä. Samoin ikä saattaa sateenkaariyhteisöissä määrittyä vain osin fyysisen iän mukaan ja osin sen mukaan, milloin on tullut mukaan yhteisöön tai esimerkiksi aloittanut sukupuolenkorjauksen (Lehtonen 2014, 50). Tällöin sateenkaarevat nuoret eivät välttämättä myöskään jaa niitä sukupolvikokemuksia, joita osa muista kalenteri-iältään samanikäisistä pitää merkityksellisinä.

Antu Sorainen (2013) on käsitellyt queer-nuoruutta pohtien "kieroonkasvamisen" mahdollisuuksia omanlaisen aikuisuuden saavuttamisessa. Sorainen perustaa pohdintansa queer-tutkija Jack Halberstamin $(2005 ; 2011)$ tutkimuksille ja queer-aikuisuuden ymmärtämiseen epäonnistumisena normien mukaisessa kasvamisessa. Sorainen korostaa, että tämä epäonnistuminen voi kyllä tarkoittaa reittien löytämistä omaan aikuisuuteen, mutta siitä voi seurata myös kipeitä kokemuksia siitä, ettei aikuisuus avannutkaan mahdollisuuksia onnellisuuteen ja parempaan elämään. Soraisen tutkimus korostaakin tarpeellisesti, ettei 
aikuistumisen myötä kaikki välttämättä "muutu paremmaksi" ja ettei queer-nuoruutta voi käsitellä vain valitettavana, onnettomana välivaiheena ennen vapautunutta aikuisuutta.

Omassa tutkimuksessani nuoret pohtivat, miten on mahdollista kuvitella aikuisuutta sateenkaari-ihmisenä, jos yhteiskunnassa hyväksytyt aikuisuuden mallit määrittyvät hetero- ja sukupuolinormatiivisesti. Sellaisesta nuoresta, joka ei voi tai halua sopia näihin malleihin, saattaa tuntua, ettei aikuisuutta voi olla lainkaan olemassa, ellei oma sateenkaarevuus mene nuoruuden aikana ohi. (Taavetti 2015a, 147-149.) Aiemmin toki onkin ollut niin, että aikuisuus on yleensä tarkoittanut sopeutumista normeihin ja esimerkiksi avioitumista omista tunteista huolimatta tai oman sukupuolen kokemuksen pysyvää piilottamista (ks. esim. suomalaisten homomiesten elämänkulkujen muutoksista Lehtonen 2009). Jack Halberstam on kuvannut aikuisuudesta tuotettujen käsitysten ahtautta sekä niihin sopimattomuuden aiheuttamaa päättäväistä oman tien etsimistä esimerkillä omasta kouluajastaan, jolloin hän määrittyi ympäristönsä näkökulmasta tytöksi:

Olen oppikoulussa 1970-luvun englannissa ja rehtori kertoo kokoontumisessa meille tytöille, että velvollisuutemme on pukeutua asianmukaisesti, jotta emme "kiihota" miesopettajia valitettaviin reaktioihin. Tämä on, hän jatkaa, hyvää harjoitusta meille, koska olemme täällä valmistaaksemme itseämme avioliittoa ja perhettä varten. Kuulen kovan äänen pääni sisällä sanovan helvettiin perhe, helvettiin avioliitto, helvettiin miesopettajat, tämä ei ole minun elämäni, tästä ei tule minun aikajanani. ${ }^{4}$ (Ferguson et al. 2007, 182.)

Queer näkökulmana aikaan siis hylkää heteronormatiivisen ajan ja tulevaisuuden. Toisaalta myös homo- ja lesboelämässä on norminsa ja elämäntarinan kertomisen mallinsa tiedostamisineen, kaapistatuloineen ja rakastumisineen - sekä yhä useammin myös vakituisine liittoineen ja lapsineen. Esimerkiksi Halberstamin käsittelyssä queer-katse aikaan pyrkii purkamaan aikuistumisen narratiivin kokonaan ja keskittymään juuri nuoruuteen ja keskenkasvuisuuteen mahdollisena queerin elämän hetkenä ilman normatiivista elämäntarinan kehystä.

\section{Sateenkaarinuoruuden muistaminen ja kertominen}

Sateenkaarinuorena aikuistuminen saattaa siis edellyttää epäonnistumista normien toteuttamisessa. Toisaalta myös itsensä nimeäminen sateenkaarevilla termeillä voi tapahtua ensin muiden pilkan, ei suinkaan itsetiedostamisen kautta (esim. Champagne 2013). Nimetyksi tuleminen ulkopuolelta ja mahdollisesti vasta aikuisuudessa ei toki tarkoita, etteikö myös silloin voisi rakentaa itselleen sopivaa menneisyyttä. Nykyiseen identiteettiin sopivan menneisyyden rakentaminen vaikuttaa lapsuuden ja nuoruuden muistamiseen. Lisäksi muisteluun vaikuttaa konteksti, eli se dialoginen tila, jonka esimerkiksi muistiedon tai elämäntarinoiden kirjoituskeruu tuottaa (muistelun dialogisesta luonteesta esim. Pöysä 2006; Savolainen 2016). Silloin, kun muistelun kontekstina on erityisesti sateenkaareva nuoruus, muistelussa saattavat korostua nykyistä itseymmärrystä selittävät kokemukset, kuten esimerkiksi aikuisen homomiehen lapsuudenkokemukset siitä, ettei ollut kuten "muut pojat" (ks. tarkemmin Taavetti 2016, 92-93). Omaan lapsuuteen ja nuoruuteen mahdollisesti yhtä lailla kuuluvat

4 "I am in grammar school in England in the 1970s, and in assembly hall the headmistress wants to let the girls know that it is our responsibility to dress appropriately so as not to 'incite' the male teachers to regrettable actions. This, she says, will be good training for us, since we are here to prepare ourselves for marriage and family. I hear a loud voice in my head saying fuck family, fuck marriage, fuck the male teachers, this is not my life, that will not be my time line." Käännös kirjoittajan. 
kokemukset siitä, että oli kuten muutkin, voivat tulla sivuutetuiksi, sillä niiden avulla ei ole mahdollista tuottaa kertomusta siitä, miten kasvoi nykyiseksi itsekseen. Tällöin omasta lapsuudesta tai nuoruudesta saatetaan etsiä kohtaa, joka tuntuu nykynäkökulmasta ensimmäiseltä tunnistettavalta sateenkaarevuuden kokemukselta. Esimerkiksi Sateenkaarinuorena nyt ja ennen -keruuseen vastannut, vuonna 1968 syntynyt mies kirjoittaa varsinaisen "heräämisen" tapahtuneen 13-vuotiaana, vaikka hän olikin ymmärtänyt olevansa "jollain lailla erilainen" jo aiemmin:

\footnotetext{
Muistan erittäin hyvin sen elokuisen päivän, kun maalta kesälomilta palaamisen yhteydessä olin selannut satunnaisesti valitsemaani viikkolehteä. Siinä oli juttu etnisesti eritaustaisesta hääparista, jonka häitä vietettiin lehden artikkelin mukaan iloisessa ilmapiirissä. Hääpari oli tumma; morsian kaunis ja siro, mutta jostain syystä huomasin katselevani tavallista kauemmin kuvaa pitkästä ja tummatukkaisesta sulhasesta, joka oli leikkaamassa hääkakkua. (SKS, Sateenkaarinuorena nyt ja ennen, sivut 300-301.)
}

Kirjoittaja kertoo, miten kuva sulhasesta palasi kiihottavana mieleen useita kertoja myöhemmin. Kuvauksensa lopuksi kirjoittaja toteaa, ettei osannut tuolloin edes ajatella olevansa homo. Hänen nykyisestä itseymmärryksestään käsin tämä varhaisen teini-iän kokemus muodostuu nykyistä identiteettiä rakentavaksi muistoksi, vaikka oman seksuaalisuuden nimeäminen tapahtui elämäntarinan mukaan vasta vuosia myöhemmin. Nykynäkökulmasta kirjoittaja toivookin, että olisi voinut välttää nuoruudessaan syyllisyyttä omista tunteistaan, ja hän puhuttelee kirjoituksensa lopussa 13-vuotiasta itseään:

Se poika olisi voinut olla enemmän iloisempi komean näköisistä tummista miehistä. "Ehkä tuollaisen sulhasen näköisen miehen minä vielä tulen löytämään", olisin sen pojan toivonut ajattelevan fantasioidessaan. Sillä tumman ja komean kaverin olen sittemmin löytänyt. (SKS, Sateenkaarinuorena nyt ja ennen, sivut 300-301.)

Siinä missä elämäntarinan kirjoittaminen tai kertominen on yleisestikin sekä itselle että muille ymmärrettävän ja hyväksyttävän kertomuksen luomista, sateenkaarevan elämän muistelu saattaa rajautua aivan erityisillä tavoilla. Erityisesti biseksuaalisuuteen on menneisyydessä suhtauduttu ohimenevänä vaiheena, eivätkä nämä käsitykset ole vieläkään täysin hälvenneet (esim. Taavetti 2015a, 45-46). Edelleen esimerkiksi sukupuolenkorjaukseen hakeutuvien transihmisten ja muunsukupuolisten kokemuksiin kuuluu, että heidän sukupuoli-identiteettiään arvioidaan, jolloin on tarpeen tuottaa itsestään kertomus yksiselitteisesti, koherentisti ja pysyvästi sukupuolittuneena ihmisenä. Tällöin erilaiset oman itsen etsimisen tai vaikkapa sukupuolten välille tai ulkopuolelle asettumisen kokemukset eivät välttämättä mahdu hyväksyttävän nuoruuden kuvauksiin. Lisäksi vähemmistöjen piirissä saattaa olla korostunut tarve tuottaa omasta elämästään enemmistölle hyväksyttävä kertomus. Erityisesti sellaisessa yhteydessä, jossa ei kerätä juuri sateenkaarevaa elämää koskevia muistoja, monet saattavat pyrkiä kuvaamaan omaa lapsuuttaan ja nuoruuttaan mahdollisimman normaalina ja ongelmattomana.

Nuoruuden muistelun tutkimuksessa onkin syytä huomioida menneet ja edelleen vallitsevat medikalisoivat käytännöt sekä psykologisoivat kehitysteoriat, jotka ovat marginalisoineet esimerkiksi seksuaali- ja sukupuolivähemmistöihin kuuluvia. Nämä vanhentuneet teoriat vaikuttavat yhä siihen, millä tavalla kerrotaan normien ulkopuolella eletystä nuoruudesta. Toisaalta myös vähemmistöjen omassa muistelussa syntyy kertomustyyppejä, kuten kaapistatulon ja itsetiedostamisen kuvauksia, jotka vaikuttavat siihen, miten omasta 
menneisyydestä kerrotaan. Esimerkiksi Nan Alamilla Boyd (2008) on analysoinut, miten hänen haastateltaviensa käsitykset siitä, millaisia kuvauksia he olettavat haastattelijan toivovan, rajaavat sitä, millaisesta sateenkaarevasta elämästä he kertovat. Tutkijan tulee olla tietoinen niistä sekä yksittäisen tutkimuksen ja siihen liittyvän vuorovaikutuksen että laajemmin yhteiskunnan ja kulttuurin tasolla vaikuttavista malleista ja rakenteista, joiden avulla kertomusta sateenkaarevasta elämästä tuotetaan muisteluhetkessä.

\section{Sateenkaarinuoruuden sukupolvikokemukset}

Myös historiallisesti tarkasteltuna sateenkaarevat nuoruuskokemukset saattavat asettua vastarintaan suhteessa erityisesti siihen, miten seksuaalisuuden sukupolvittaista muutosta on analysoitu. Esimerkiksi Osmo Kontulan ja Elina Haavio-Mannilan (1995) tutkimusten seksuaalisuuden sukupolvien malli kuvaa seksuaalista vapautumista ja tasa-arvoistumista tavalla, johon eivät sovi ei-heteroseksuaalisten nuorten kokemukset (ks. tarkemmin Taavetti 2014). Nämä havainnot siitä, etteivät suoraan seksuaalisuuteen tai sukupuoleen keskittyvät sukupolven määrittelyt kunnolla kata sateenkaarevia nuoruuden kokemuksia, eivät ole tietenkään erityisen yllättäviä. Kiinnostava kysymys mielestäni onkin, millä tavalla seksuaalisuuden ja sukupuolen normien haastaminen saattaa haastaa laajemmin käsityksiä yhteiskunnallisista sukupolvista.

Koska sukupolvi on korostuneesti nuoruusajan perusteella määrittyvä, osa nuoruudestaan kirjoittavista voi käyttää sukupolvea myös retorisena välineenä eli tapana kertoa nuoruutensa kokemuksista ja liittää ne nuoruutensa historialliseen aikaan. Oi nuoruus -kokoelmaa tutkineet Kaisa Vehkalahti ja Leena Suurpää $(2014,14)$ pohtivat, miten mennyttä nuoruutta kuvatessa tehdään rinnastuksia ja vertailuja nykynuoruuden ja oman nuoruuden välillä sekä arvioidaan eri sukupolvien nuoria yhdistäviä ja erottavia tekijöitä. Tällaista arviointia löytyy Sateenkaarinuorena nyt ja ennen -kokoelmasta erittäin vähän. Yksikään kirjoittaja ei käytä sukupolven käsitettä.

Sukupolveen liittyvien kuvausten puuttuminen ei toki tarkoita, etteivätkö sateenkaarevasta nuoruudesta kirjoittavat liittäisi omia kokemuksia aikaan, jolloin he ovat eläneet nuoruuttaan. Esimerkiksi kirjoituskeruuaineiston vanhin kirjoittaja, vuonna 1940 syntynyt nainen, käsittelee samansukupuolisen halun ja rakkauden näkymättömyyttä omassa menneisyydessään: "Tässä nuoruuteni maailmassa homoseksuaalisuus oli jotain sellaista, jota ei ollut olemassakaan. Vaisto vain sanoi, että tuntemuksistaan ei voi puhua kenellekään. Nuorena en tiennyt ilmiölle edes nimeä." (SKS, Sateenkaarinuorena nyt ja ennen, sivut 328-329.) Kirjoittamalla "nuoruutensa maailmasta" vastaaja asettaa omat kokemuksensa osaksi yhteiskunnallista aikaansa. Tämän kirjoittajan elämässä vaikeneminen ei tosin päättynyt aikuisuudessakaan, sillä hän on koko elämänsä ajan paljastanut rakkautensa vain päiväkirjalleen, ja työssään opettajana hän on kokenut, ettei homoseksuaalisuus ole saanut näkyä koulussa myöhemminkään. Hänen mukaansa osa elämästä jäi tämän vaikenemisen vuoksi elämättä.

Siihen, ettei sukupolvi toimi sateenkaarinuoruudesta kirjoittavien retorisena keinona, vaikuttaa varmasti osaltaan sukupolveen yhteiskunnallisena ilmiönä liittyvä julkisuus ja toisaalta sateenkaareviin nuoruudenkokemuksiin menneisyydessä liitetty yksityisyys tai, kuten edellä, jopa salaaminen. Sateenkaarevaa nuoruutta eläneillä ja sitä myöhemmin muistelevilla ei ole elämänsä tämän osa-alueen osalta sellaista julkista ryhmää, johon rinnastaa omat kokemuksensa ja johon suhteessa eroja ja yhtäläisyyksiä olisi mahdollista määrittää. Mikäli 
keruun kirjoittajina olisi ollut laajemmin sellaisia muistelijoita, joiden nuoruus olisi vahvasti kiinnittynyt esimerkiksi Setan toimintaan tai muuten poliittiseen työhön sateenkaarioikeuksien puolesta, tilanne olisi voinut olla erilainen. Tällaiset kertojat saattaisivat määrittää omaa paikkaansa suhteessa sateenkaareviin sukupolviin, jotka ovat tunnistettavissa aktivismissa ja järjestötoiminnassa (ks. Lehtonen 2014; seksuaali- ja sukupuolivähemmistöjen asemasta suomalaisessa julkisuudessa ja poliittisessa keskustelussa ks. myös Juvonen 2015).

Sateenkaarinuorena nyt ja ennen -aineisto antaa joitakin välähdyksiä siitä, millaisia populaarikulttuurin ilmiöitä omaa nuoruuttaan muistelevat kuvaavat. Pohtiessani sateenkaarevan nuoruuden muistamista ja sukupolvia olen täydentänyt näitä välähdyksiä Helsingin Sanomien Nyt-viikkoliitteen vuoden 2015 itsenäisyyspäivänä keräämällä koosteella Tärkeimmät sateenkaarihetket (Sarhimaa 2015). Molemmissa aineistoissa yhteisenä kertomisen kontekstina on sateenkaarevuus, eli kertojat ovat muistelleet erityisesti seksuaalisuuden ja sukupuolen moninaisuuden kokemuksiin liittyviä kulttuuri-ilmiöitä. Toisin kuin Sateenkaarinuorena nyt ja ennen -keruussa, Tärkeimmissä sateenkaarihetkissä ei pyydetty miettimään nuoruudenaikaisia kokemuksia, mutta silti valtaosa esiin nostetuista kulttuuri-ilmiöistä oli sellaisia, joihin kertoja oli tutustunut nuorena. Kummassakaan yhteydessä ei käytetty sukupolven käsitettä, eli kertojat eivät ole välttämättä pohtineet, määrittävätkö nämä muistot jollain tapaa laajemmin heidän ikäisiään.

Sateenkaarinuorena nyt ja ennen -keruun kirjoituksissa näkyy, miten vasta 1990-luvulla on alkanut esiintyä laajemmin sellaisia populaarikulttuurin ilmiöitä tai julkisuuden henkilöitä, jotka ovat olleet vastaajien sateenkaarinuoruudessa merkittäviä (ks. tarkemmin Taavetti 2016). Ainoa sekä kirjoituskeruussa että Tärkeimmissä sateenkaarihetkissä toistuva maininta liittyy sekin 1990-luvun loppuun: molemmissa aineistoissa mainitaan Salatut elämät -tv-sarja, jonka vuonna 1999 esitelty Kalle-hahmo oli merkittävä muutos suomalaisen viihdekuvaston homohahmoissa (Kallesta ks. Kekki 2000). Kallen hahmo oli tarjonnut esimerkiksi yhdelle kirjoittajalle tukea hänen valmistautuessaan asepalvelukseen ja myöhemmin sarjan Larin ja Eliaksen rakkaussuhde tuotti nuorelle naiselle iloa stereotyyppejä vastustavana homoparina.

Aiemmilta vuosikymmeniltä maininnat populaarikulttuurin sateenkaarimuistoista ovat vähäisempiä, mikä toki osaltaan selittyy sillä, että aineistot painottuvat nuorempiin muistelijoihin. Varhaisin maininta Sateenkaarinuorena nyt ja ennen -keruussa koskee Monsieur Mossea, Suomen ensimmäistä julkihomoa, jonka elämää käsiteltiin erityisesti Hymy-lehdessä 1960-luvun lopussa ja 1970-luvun alussa (Mossesta ja Hymystä ks. Juvonen 2002, 105-114). Vanhemmat kirjoittajat eivät muistelleet myöskään ulkomaisia julkisuuden henkilöitä ennen 1990-luvun vaihdetta ja Queen-yhtyeen laulaja Freddie Mercurya koskevia mainintoja. Toisaalta populaarikulttuurin tuotteiden queer-kulttuurinen merkityksellisyys voi syntyä myös toisin katsomalla ja tulkitsemalla. Tärkeimmissä sateenkaarihetkissä tästä on esimerkkinä 1990-luvun Valion mainos, jossa nuori nainen pudottaa kihlasormuksensa kaivoon. Vaikka nainen mainoksessa valitsee piimän miehen sijaan, 1960-luvun alussa syntyneelle naiselle tämä mainos henki "rehvakkuutta" ja heteronormin hylkäämistä.

Se, minkä ikäinen kertoja kuvaa olleensa kohdatessaan itselleen merkityksellisen teoksen, vaihtelee aivan lapsuudesta kolmikymppiseen. Sukupolvittaisessa populaarikulttuurin kokemusten tarkastelussa usein painotetaan varhaisnuoruuden tai esiteini-iän kokemusten merkitystä (esim. Tormulainen 2018) tai mannheimlaisittain noin 17 vuoden ikää. 
Sateenkaarevat avainkokemukset eivät välttämättä asetu samaan ikään, vaan merkittävät kokemukset voivat kiinnittyä eri elämänvaiheisiin. Merkittävien populaarikulttuurituotteiden ei tarvitse myöskään olla välttämättä uusia. Tärkeimmissä sateenkaarihetkissä mainitaan Tove Janssonin muumikirjat sekä Leevi and the Leavingsin "Poika nimeltä Päivi" -kappale, jotka kirjoittajat muistavat merkityksellisinä, vaikka he ovat löytäneet ne paljon niiden ilmestymisen jälkeen. Tällaista vanhempien sukupolvien kulttuurituotteiden kierrättämistä ja toistuvaa merkityksellistymistä voi pitää esimerkkinä Elizabeth Freemanin (2000; 2010, 62-65) aikadragiksi (temporal drag) nimeämästä ilmiöstä, eli queer-nuorten samastumisesta aiempien sukupolvien kokemuksiin (käsitteestä ja sen ongelmista tarkemmin Taavetti 2018, 83-84). Omaan aikaan ja omaan sukupolveen liittyvien samastuttavien populaarikulttuurin ilmiöiden puuttuessa nuoruudessaan voi kokea tärkeiksi aiempien sukupolvien nuoruuden välähdykset ja jopa samastua kokonaan vanhempaan sukupolveen kuin mihin kalenteri-ikänsä puolesta kuuluu.

\section{Sateenkaarevampi sukupolvi?}

Olen tarkastellut tässä katsauksessa sukupolven käsitettä suhteessa sateenkaarinuoruuden muistamiseen ja queer-teorian tuottamiin käsityksiin ajasta. Katsaukseni tavoitteena on ollut kannustaa nuoruuden muistamista pohtivia arvioimaan, millaisia nuoruuksia heidän käyttämänsä sukupolven käsite tavoittaa ja keitä tai millaisia muistoja se kenties sulkee ulkopuolelle, sekä pohtimaan sukupuolen ja seksuaalisuuden kokemisen merkitystä sukupolven käsitteen kannalta. Olen pohtinut sateenkaarinuoruuden mahdollista eriaikaisuutta, sateenkaarevien sukupolvien mahdollisuuksia sekä sitä, millaiset rakenteet ja oletukset vaikuttavat sateenkaarevan nuoruuden muisteluun. Olen kirjoituksessani myös hahmotellut, millaisia muistoja populaarikulttuurista sateenkaarinuoruuden kertomuksista löytyy.

Katsaukseni lopuksi haluan vielä pohtia, voisiko sateenkaarinuoruuden muistoista löytyä jotakin, mikä riittäisi muodostamaan sukupolvikokemuksen. Kuten Matti Virtanen (2003, 63) huomauttaa, sukupolvet on usein mahdollista hahmottaa vasta jälkikäteen, riittävän pitkän ajallisen perspektiivin päästä. Saattaa siis olla, että nykyhetkessä tai lähimenneisyydessä mahdollisesti muodostuneet sateenkaarevat sukupolvet eivät vielä erotu muisteluaineistoista. Lisäksi Sateenkaarinuorena nyt ja ennen -kirjoituskeruun vastaukset saattavat olla aineistona liian pieni ja hajanainen sukupolvittaisen analyysin tekemiseen.

Silti pidän mahdollisena, että vuonna 2013 käyty kampanjointi tasa-arvoisesta avioliittolaista muodostuisi sukupolvea muokkaavaksi kokemukseksi. Keskustelun avioliittolaista mainitsi jollain tavoin vastauksissaan 15 Sateenkaarinuorena nyt ja ennen -keruun kirjoittajaa siinä missä aiemmat lainsäädännön muutokset ja yhteiskunnalliset keskustelut, kuten vuoden 2001 parisuhdelaki, mainittiin vain yksittäisissä tekstissä. Tämä kertoo osaltaan kirjoitusajankohdasta, sillä keväällä 2014 kirjoittaneilla Tahdon 2013 -kampanja oli tuoreena mielessä. Kirjoittajajoukko oli myös varsin nuorta, eikä heillä siis ollut välttämättä omakohtaisia muistikuvia aiemmista kamppailuista. Kampanjan ja siitä käydyn keskustelun merkitys näkyy teksteissä moninaisena. Yhtäältä kirjoittajat kertovat osallistuneensa kampanjaan ja kokeneensa jopa velvollisuutta toimia yhteiskunnallisesti. Toisaalta keskustelu avioliittolaista oli heitä satuttavaa ja jotkut kokivat pettyneensä suomalaiseen yhteiskuntaan.

Arvioin, että Tahdon 2013 -kampanja ja kokemus siitä, että aiemmin vähemmistökysymykseksi mielletyt yhdenvertaisuusasiat nousivat ennennäkemättömällä tavalla poliittisen 
keskustelun kohteeksi, on voinut olla sateenkaareville kirjoittajille erityisen merkityksellinen. Tällöin kyse ei ole siitä, että tasa-arvoinen avioliittolaki itsessään olisi heille loputtoman keskeinen, vaikka toki se monille oli erittäin tärkeä, tai että avioliitto-oikeus olisi sateenkaariaktivismin lopullinen tavoite (avioliittokeskustelusta queer-ajan näkökulmasta ks. Boellstorff 2007). Kyse on nimenomaan kampanjoinnin tuottamasta yhteiskunnallisen muutoksen kokemuksesta. Nähtäväksi jää, näyttäytyvätkö tämän kampanjan omassa nuoruudessaan kokeneet erityisenä ryhmänä, jopa mobilisoituneena sukupolvena, kun tulevaisuudessa kerätään seksuaali- ja sukupuolivähemmistöihin kuuluvien tai muuten sateenkaarevien kirjoittajien muistitietoa.

\section{Lähteet}

\section{Tutkimusaineisto}

Suomalaisen Kirjallisuuden Seura, Perinteen ja nykykulttuurin kokoelma (Suomalaisen Kirjallisuuden Seura): Sateenkaarinuorena nyt ja ennen, 2014.

Sarhimaa, Jutta. 2015. "Tässä ovat suomalaisen kulttuurin tärkeimmät sateenkaarihetket: Esa Saarisen Poikarakkaudesta Antti Tuiskun Peto on irti -videoon." Helsingin Sanomat, Nyt-viikkoliite 5.12.2015.

\section{Kirjallisuus}

Boellstorff,Tom.2007."WhenMarriageFalls:QueerCoincidencesinStraightTime."GLQ:AJournal of Lesbian and Gay Studies 13(2): 227-248. https://doi.org/10.1215/10642684-2006-032.

Boyd, Nan Alamilla. 2008. "Who is the Subject? Queer Theory Meets Oral History." Journal of the History of Sexuality 17(2): 177-189. https://doi.org/10.1353/sex.0.0009.

Champagne, John. 2013. "Foucault and Queer (Un)Historicism." PMLA: Publications of the Modern Language Association of America 128(4): 1005-1006.

Edelman, Lee. 2004. No Future: Queer Theory and the Death Drive. Durham: Duke University Press. https://doi.org/10.1215/9780822385981.

Ferguson, Roderick A., Lee Edelman, Tan Hoang Nguyen, Carolyn Dinshaw, Elizabeth Freeman, Carla Freccero, Annamarie Jagose, Christopher Nealon ja Jack Halberstam. 2007. "Theorizing Queer Temporalities: A Roundtable Discussion." GLQ: A Journal of Lesbian and Gay Studies 13(2): 177-195.

Freeman, Elizabeth. 2007. "Introduction." GLQ: A Journal of Lesbian and Gay Studies 13(2-3): 159-176.

Freeman, Elizabeth. 2000. "Packing History, Count(Er)Ing Generations." New Literary History 31 (4): 727-744. https://doi.org/10.1353/nlh.2000.0046.

Freeman, Elizabeth. 2010. Time Binds: Queer Temporalities, Queer Histories. Durham: Duke University Press. https://doi.org/10.1215/9780822393184.

Häkkinen, Antti. 2013. "Suomalaiset sukupolvet, elämänkulku ja historia: Sukupolvesta sukupolveen." Teoksessa Sosiaalinen albumi: Elämäntavat sukupolvien murroksissa, toimittaneet Antti Häkkinen, Anne Puuronen, Mikko Salasuo ja Anni Ojajärvi, 21-55. Helsinki: Nuorisotutkimusseura. 
Halberstam, Jack. 2005. In a Queer Time and Place: Transgender Bodies, Subcultural Lives. New York: New York University Press.

Halberstam, Jack. 2011. The Queer Art of Failure. Durham: Duke University Press. https://doi. org/10.1215/9780822394358.

Hekanaho, Pia Livia. 2010. “Queer-teorian kummia vaiheita.”Teoksessa Käsikirja sukupuoleen, toimittaneet Tuula Juvonen, Leena-Maija Rossi ja Tuija Saresma, 144-155. Tampere: Vastapaino.

Hoikkala, Tommi ja Petri Paju. 2008. "Entä nuoremmat sukupolvet? Sukupolvitutkimus ja nuorisopolitiikka." Teoksessa Kenen sukupolveen kuulut? Suurten ikäluokkien tarina, toimittaneet Semi Purhonen, Tommi Hoikkala ja J. P. Roos, 270-294. Helsinki: Gaudeamus.

Jagose, Annamarie. 1996. Queer Theory: An Introduction. New York: New York University Press.

Jõesalu, Kirsti. 2016. "We were the Children of a Romantic Era: Nostalgia and the Nonideological Everyday through the Perspective of a 'Silent Generation.'. Journal of Baltic Studies 47(4): 557-577. https://doi.org/10.1080/01629778.2016.1248685.

Jokinen, Kimmo. 2003. "Kirjoitetut rockmuistot: Musiikki muistina." Teoksessa Hyvää pahaa rock ' $n$ ' roll: Sosiologisia kirjoituksia rockista ja rockkulttuurista, toimittanut Kimmo Saaristo, 40-61. Helsinki: Suomalaisen Kirjallisuuden Seura.

Juvonen, Tuula. 2015. Kaapista kaapin päälle: Homoseksuaaliset ihmiset ja heidän oikeutensa edustuksellisessa politiikassa. Tampere: Vastapaino.

Juvonen, Tuula. 2002. Varjoelämää ja julkisia salaisuuksia. Tampere: Vastapaino.

Kekki, Lasse. 2000. "Hyvää homoa tarvitaan aina: Vai tarvitaanko?" Teoksessa Populaarin lumo: Mediat ja arki, toimittaneet Anu Koivunen, Susanna Paasonen ja Mari Pajala, 274308. Turku: Turun yliopisto.

Kontula, Osmo ja Elina Haavio-Mannila. 1995. Matkalla intohimoon: Nuoruuden hurma ja kärsimys seksuaalielämäkertojen kuvaamana. Porvoo: Werner Söderstöm Osakeyhtiö.

Lehtonen, Jukka. 2009. "The Diverse Intimate Relationships of Non-Heterosexual Finnish Men." NORMA: Nordic Journal of Masculinity Studies 4(1): 66-82.

Lehtonen, Jukka. 2014. "Muistot ja ajallisuus: Setan nuorten toiminta muutoksessa." SQS Suomen Queer-Tutkimuksen Seuran lehti 8(1): 44-57.

Lehtonen, Jukka. 2006. "Seksuaalisuuden ja sukupuolen moninaisuus koulun käytännöissä ja nuorten elämässä." Teoksessa Pysäytyskuvia: Sukupuoli ja seksuaalisuus nuorten elämässä ja koulun arjessa, toimittanut Eija Asikainen, 49-66. Joensuu: Joensuun yliopisto.

Lehtonen, Jukka. 1998. "Young People-s Definitions of their Non-Heterosexuality."Teoksessa Unification and Marginalisation of Young People, toimittanut Helena Helve, 185-192. Helsinki: Nuorisotutkimusseura.

Mannheim, Karl. 1952. "The Problem of Generations." Teoksessa Essays on the Sociology of Knowledge, Karl Mannheim, 276-322. London: Routledge.

Piispa, Mikko. 2018. Yhdeksän sanaa Y-sukupolvesta. Helsinki: Kustannusosakeyhtiö Teos.

Pöysä, Jyrki. 2006."Kilpakirjoitukset muistitietotutkimuksessa.”Teoksessa Muistitietotutkimus: Metodologisia Kysymyksiä, toimittaneet Outi Fingerroos, Riina Haanpää, Anne Heimo ja Ulla-Maija Peltonen, 145-171. Helsinki: Suomalaisen Kirjallisuuden Seura. 
Roos, J. P. 1987. Suomalainen elämä: Tutkimus tavallisten suomalaisten elämäkerroista. Helsinki: Suomalaisen Kirjallisuuden Seura.

Salasuo, Mikko. 2014. “Sukupolveni soundtrack: Populaarimusiikki 1970-luvulla syntyneiden kirjoitetuissa nuoruusmuistoissa." Teoksessa Nuoruuden sukupolvet: Monitieteisiä näkökulmia nuoruuteen eilen ja tänään, toimittaneet Kaisa Vehkalahti ja Leena Suurpää, 178-199. Helsinki: Nuorisotutkimusseura.

Savolainen, Ulla. 2016. "The Genre of Reminiscence Writing." Teoksessa Genre - Text Interpretation: Multidisciplinary Perspectives on Folklore and Beyond, toimittaneet Kaarina Koski, Frog ja Ulla Savolainen, 203-231. Helsinki: Suomalaisen Kirjallisuuden Seura.

Sorainen, Antu. 2013. "Kieroonkasvamisen mahdollisuudet." Nuorisotutkimus 31(1): 23-42.

Taavetti, Riikka. 2015a. "Olis siistiä, jos ei tarttis määritellä...": Kuriton ja tavallinen sateenkaarinuoruus. Helsinki: Nuorisotutkimusseura \& Seta.

Taavetti, Riikka. 2018. Queer Politics of Memory: Undisciplined Sexualities as Glimpses and Fragments in Finnish and Estonian Pasts. Helsinki: Helsingin yliopisto.

Taavetti, Riikka. 2016. "Reflecting the Queer Me. Memories of Finnish Queer Youth from the 1950s Onwards." Lambda Nordica (3-4): 81-107.

Taavetti, Riikka. 2014. "'Seksi oli rakkauden hinta': Seksuaalisuus eilisen nuoruudessa." Teoksessa Nuoruuden Sukupolvet. Omaelämäkerrallinen katse suomalaiseen nuoruuteen, toimittaneet Kaisa Vehkalahti ja Leena Suurpää, 88-109. Helsinki: Nuorisotutkimusseura.

Taavetti, Riikka. 2015b. "Sukupolvittunut sateenkaaripolitiikka." Nuorisotutkimus 33(2): 62-65.

Taavetti, Riikka ja Jukka Lehtonen. 2018. "Metodologisia ja eettisiä kysymyksiä sateenkaarinuorten etnografisessa ja osallistavassa tutkimuksessa." Teoksessa Miten tutkia nuoria ja nuorisotyötä?, toimittaneet Päivi Honkatukia ja Tomi Kiilakoski, 274-290. Tampere: Vastapaino.

Tormulainen, Aino. 2018. Tyttöenergialla kasvaneet: Postfeministisen populaarikulttuuriilmiön yhdessä muistellut merkitykset. Helsinki: Nuorisotutkimusseura.

Vehkalahti, Kaisa ja Leena Suurpää. 2014. "Johdanto: Nuoruus, sukupolvet ja oman elämän kirjoittaminen." Teoksessa Nuoruuden sukupolvet: Monitieteisiä näkökulmia nuoruuteen eilen ja tänään, toimittaneet Kaisa Vehkalahti ja Leena Suurpää, 5-29. Helsinki: Nuorisotutkimusseura.

Virtanen, Matti. 2001. Fennomanian perilliset: Poliittiset traditiot ja sukupolvien dynamiikka. Helsinki: Suomalaisen Kirjallisuuden seura.

Virtanen, Matti. 2003. "Nuoren Suomen traditio sukupolvien ketjuna."Teoksessa Nuoruuden vuosisata: Suomalaisen nuorison historiaa, toimittaneet Sinikka Aapola ja Mervi Kaarninen, 35-65. Helsinki: Suomalaisen Kirjallisuuden Seura.

Vuori, Jaana ja Suvi Ronkainen. 2002. "Fennomaaniset miespolvet." NaistutkimusKvinnoforskning 15(2): 69-72.

VTT, FM Riikka Taavetti työskentelee Helsingin yliopistossa poliittisen historian tutkijana ja tutkii queer-muistitietoa ja muistin politiikkaa Suomessa ja Virossa. 